\title{
DIET OF THE NEWT, TRITURUS CARNIFEX (LAURENTI, 1768), IN THE FLOODED KARST SINKHOLE POZZO DEL MERRO, CENTRAL ITALY
}

\author{
Antonio Romano ${ }^{*}$, Sebastiano Salvidio ${ }^{2}$, Roberto Palozzi ${ }^{1,3}$, and Valerio Sbordoni ${ }^{1}$
}

\begin{abstract}
Karst habitats host a high number of specialized organisms that contribute to complex and peculiar food webs. In underground aquatic habitats, vertebrates are the top predators that strongly influence and regulate prey communities. In this study, the diet of the Italian crested newt, Triturus carnifex, in the world's deepest karst phreatic sinkhole, the Pozzo del Merro in Latium, central Italy, was analyzed. We obtained both stomach and fecal contents from twenty adult newts (ten females and ten males) sampled in summer 2010. Availability of prey in the sinkhole also was determined. Prey items were identified and classified into ten ecological groups. At Pozzo del Merro, during the summer, the aquatic stage of T. carnifex was specialized on the pre-imaginal stages of the small China-mark, Cataclysta lemnata. The recently described endemic stygobitic crustacean Niphargus cornicolanus was not found in stomach contents. Finally, our results showed that analyses of stomach and fecal contents may provide different information on the diet of newts in their aquatic phase.
\end{abstract}

\section{INTRODUCTION}

Flooded sinkholes are typical elements of karst and may host a relatively high level of biological diversity (e.g., Schmitter-Soto et al., 2002). Among vertebrates, few amphibian species are restricted to karst environments (Weber, 2004; Köhler et al., 2010; Sket, 1997), but more typically, they utilize karst as one of a variety of suitable habitats. In the Mediterranean, karst habitats are mainly associated with carbonate rocks (Lewin and Woodward, 2007). Although Mediterranean amphibians are widespread in surface habitats in the karst (Romanazzi and Bonato, 2011; Romano et al., 2010; SchmitterSoto et al., 2002), few studies have examined their ecology in karst ecosystems (e.g., Schabetsberger and Jersabek, 1995; Schabetsberger et al., 1995). Scanty ecological information is available for amphibian populations living in flooded sinkholes.

In Europe, most amphibians are strictly protected by the European directive 92/43/EEC (the so-called habitats directive), which is aimed at the creation of an ecological network in Europe to preserve biodiversity. Among newts that occur in Italy, only the Italian crested newt, Triturus carnifex (Laurenti, 1768), is in annex II of the habitats directive that lists animals of community interest whose conservation requires the designation of special areas of conservation.

When a strictly protected amphibian species and an endemic or rare invertebrate species coexist, their ecological relationships as predator and prey are of importance for planning adequate conservation measures. In the study site, a deep, flooded sinkhole in central Italy (Fig. 1), ecological studies were particularly required because, beginning in 2003, the invasive aquatic Brazilian tropical fern Salvinia molesta D.S. Mitchell spread and soon covered the surface of the lake in the bottom of the study site, replacing the previously dominant Lemna minor L. with an approximately $5 \mathrm{~cm}$ thick vegetative layer upon which terrestrial vegetation had begun to grow (Giardini, 2003, 2004). The ecological consequences of this rampant invasion were unknown, and in March 2009 a Salvinia molesta eradication program started, as recommended in Giardini (2003). As a result, L. minor had largely been reestablished as the dominant water surface vegetation by spring 2009.

We studied the diet of the Italian crested newt to determine whether the endemic crustacean recently discovered in Pozzo del Merro was preyed upon by newts, to examine whether the newts show selectivity in feeding, and to compare the information obtained analyzing both stomach and fecal contents. We also checked to see whether the sex of the newts biased their choice of prey.

\section{Study Site}

The sinkhole Pozzo del Merro is located at $140 \mathrm{~m}$ a.s.l., on the southern slopes of Cornicolani Mountains (Lat. N $42^{\circ} 02^{\prime} 21^{\prime \prime}$, Long. E $12^{\circ} 40^{\prime} 55^{\prime \prime}$, Latium, central Italy) and is included in the natural reserve Macchia di Gattaceca e Macchia del Barco (Fig. 1a). The sinkhole is the deepest

\footnotetext{
*Corresponding author: antonioromano71@gmail.com

${ }^{1}$ Dipartimento di Biologia, Università di Roma "Tor Vergata", Via Della Ricerca Scientifica, I-00133 Roma, Italy

${ }^{2}$ DIP.TE.RIS., Università di Genova, Corso Europa, 26, I-16132 Genova, Italy

${ }^{3}$ DAF, Dipartimento di tecnologie, ingegneria e scienze dell'Ambiente e delle

Foreste, Università di Viterbo "Tuscia", Via S. C. de Lellis, 01100, Viterbo, Italy
} 


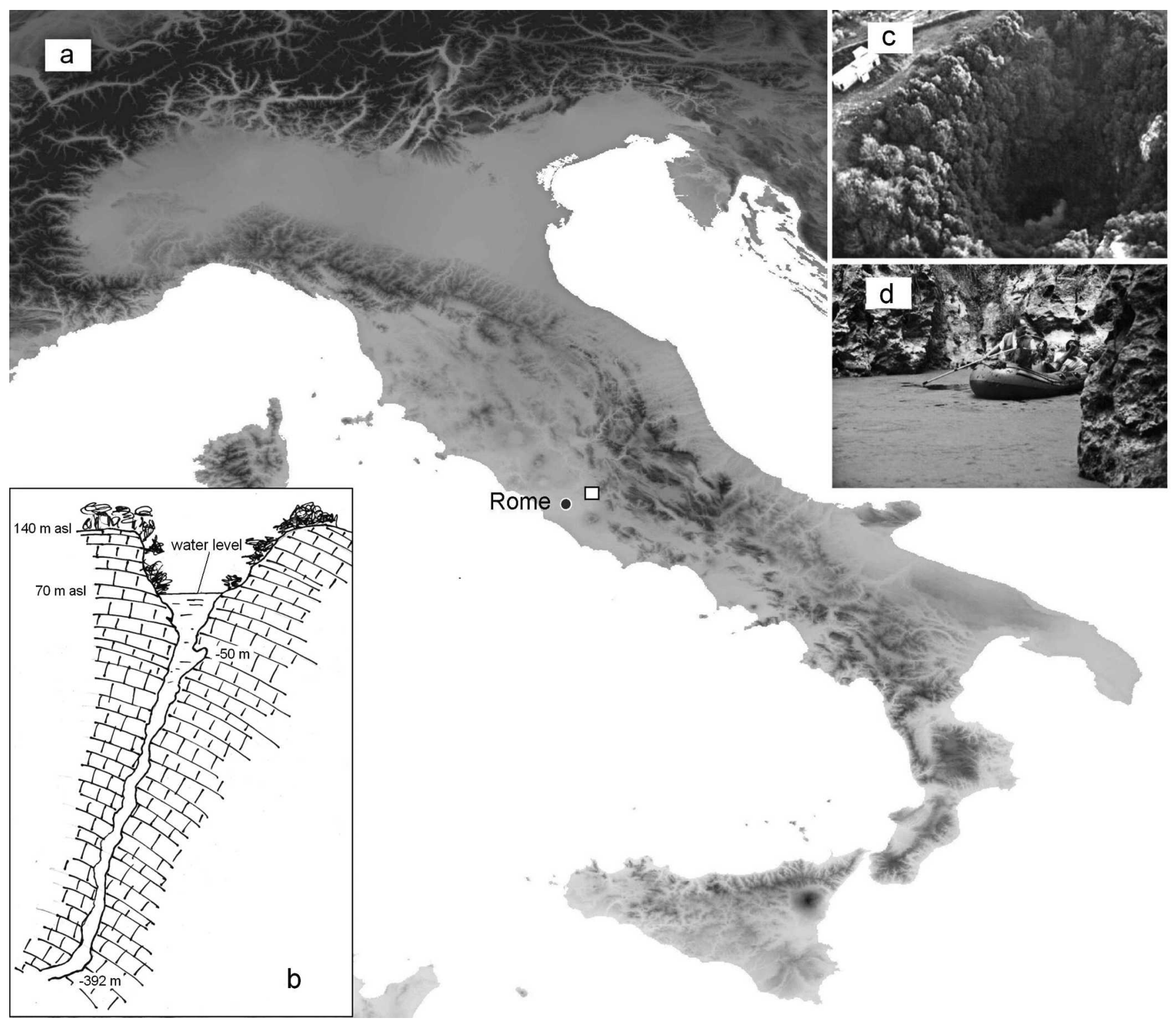

Figure 1. (a) Location of the study site, the flooded sinkhole Pozzo del Merro, in central Italy (white square). (b) Vertical geologic section. (c) The sinkhole as seen from above. (d) Sampling of the newt Triturus carnifex with a long-handled dip net maneuvered from a rubber boat.

flooded karst sinkhole in the world (about $460 \mathrm{~m}$; Caramanna, 2002; Gary et al., 2003); its flooded part extends at least $392 \mathrm{~m}$ below the water table (Fig. 1b). Pozzo del Merro is funnel-shaped, with a diameter of about $160 \mathrm{~m}$ at ground level, narrowing to $25 \mathrm{~m}$ at the water surface at about $70 \mathrm{~m}$ depth (Fig. 1b,d). Below this depth the flooded sinkhole continues down as a nearly vertical conduit with several minor cavities along the walls (Fig. 1b). The water temperature of $15.9{ }^{\circ} \mathrm{C}$ is constant throughout the sinkhole (Palozzi, et al., 2010). The water chemistry is bicarbonate-calcic, and samples collected down the water column showed a progressive reduction of $\mathrm{pH}$ from neutrality up to a minimum value of 6.57 at about $100 \mathrm{~m}$ (Palozzi et al., 2010).

\section{BIODIVERSITY AssESSMENT}

In 2005, an endemic species of amphipod crustacean was described from Pozzo del Merro, Niphargus cornicolanus Iannilli \& Vigna Taglianti, 2005. Four amphibians are found there, the Italian crested newt Triturus carnifex (Laurenti, 1768), the smooth newt Lissotriton vulgaris (Linnaeus, 1758), the Apennine frog Rana italica Dubois 1987, and the common toad Bufo bufo (Linnaeus, 1758). However the two anurans are found only sporadically, while $T$. carnifex is the dominant newt (capture ratio T.carnifex/L.vulgaris $=30: 1$, A. Romano, unpublished data). The Italian crested newt is a large-bodied newt that occurs in Italy, southern Switzerland, Slovenia, Istria, and some regions of Austria, the Czech Republic, and Hungary 
(see Vanni et al., 2007). Triturus carnifex prefers deep and permanent water bodies (Andreone and Marconi, 2006; Vanni et al., 2007).

\section{Methods}

\section{SAMPLing Method}

For this study, only adult newts were sampled. Twentytwo newts were captured on August 12, 2010, with a longhandled dip net $3.5 \mathrm{~m}$ in length, maneuvered from a boat (Fig. 1d). Newts were captured when surfacing to breathe. Newts were measured by snout-vent length, weighed, anesthetized in tricaine methanesulphonate (MS-222; Novartis). Their stomachs were flushed using a $20 \mathrm{ml}$ syringe filled with water joined to a silicone catheter $1.0 \mathrm{~mm}$ in diameter. The flushing was repeated until no further content came out (Joly, 1987; Salvidio, 1992; Vignoli et al., 2007). Two newts had empty stomachs, leaving twenty subject to further analysis. Food items still present in the oral cavity after flushing were carefully removed by entomological forceps. Newts were housed in an aquarium for approximately sixteen hours after flushing to verify their return to normal activity and then released at the capture site. Fecal matter produced by the newts during their housing were also collected to obtain digested prey. Thus feeding material was obtained from two sources, stomach contents (STO) and feces (FEC). STO were individually assigned, but since newts were housed in the same aquarium all FEC were pooled.

Prey availability (AVA) was sampled in the aquatic environment of the sinkhole by a dip net measuring $60 \mathrm{~cm}$ by $30 \mathrm{~cm}$ with a $0.1 \mathrm{~mm}$ mesh. We attempted to obtain samples that were representative of the three groups into which aquatic invertebrates may be divided. We used the dip net to sample pleustonic invertebrates near the water surface, nektonic invertebrates within the top $3 \mathrm{~m}$ of the water column, and benthic invertebrates from the top $3 \mathrm{~m}$ on the walls of the sinkhole below the water surface. All those habitats were sampled ten times. STO, FEC, and AVA samples were preserved in $90 \%$ ethanol, and identification was made using a stereomicroscope.

The newt sex ratio was expressed as the proportion of mature males: males/(males + females) (Wilson and Hardy, 2002). The vacuity index was calculated as the percentage of empty stomachs out of the total examined. Because variances were not homogeneous, Welch's test for unequal variances was used to determine males-females snout-vent length and weight differences. The Mann-Whitney U test was used to disclose differences in the number of prey swallowed by males and females. The non-parametric Spearman's rank correlation was used to detect any differences in prey between the two sources, stomach and feces, and between prey (STO + FEC) and trophic availability. To compare the results obtained using two different sources (STO and FEC) and to detect sex-related feeding differences, three diversity indices were used, the number of taxa, the Simpson index, which measures evenness of the community from 0 to 1 and is the mostused statistic to compare small samples (Magurran, 2004), and the analysis of similarity (ANOSIM) on the BrayCurtis dissimilarity measure, which is widely used to analyze animal communities, and in particular, those of freshwater invertebrates, with Bonferroni correction. ANOSIM is a non-parametric significance test between two or more groups, based on any distance measure (Clarke, 1993). Costello's (1990) graphical representation, modified by using prey-specific abundance (PI) instead of percentage abundance (Amundsen et al., 1996), was made to estimate the importance of particular food items in the diet of the newts and to assess their foraging strategy. This method classifies prey selection by plotting prey-specific abundance $\mathrm{PI}$ on the $\mathrm{Y}$-axis against frequency of occurrence on the $\mathrm{X}$ axis in the predator stomachs (Fig. 2). PI is defined as the proportion of a prey type among of all prey items in only those individuals in which that prey type occurs (Amundsen et al., 1996). This graphical approach allows for determination of prey importance, the feeding strategy of the predator, and the two components that contribute to the population's total niche width, within-phenotypic and between-phenotypic. The modified Costello's graph provides information on feeding patterns that might not be inferred from single-diet indexes.

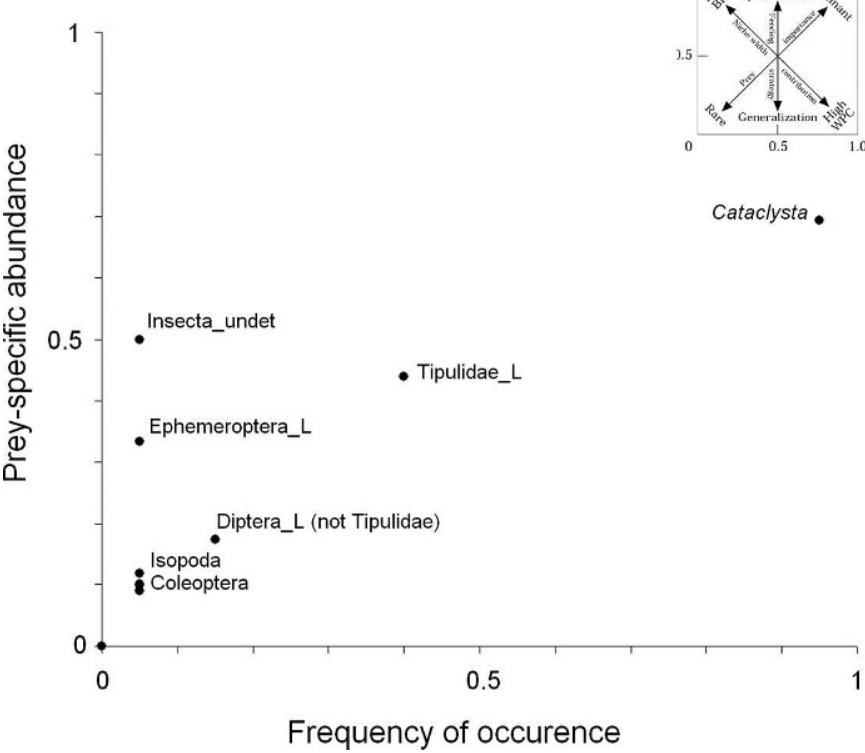

Figure 2. Feeding strategy, based on stomach contents, of the newt Triturus carnifex in the Pozzo del Merro visualized using the Costello graphic as modified by Amundsen et al. (1996). The small square shows the interpretation of the plot, where BPC is between-phenotype component of the population's total niche width and WPC is the within-phenotype component. Some taxa with low abundance and low frequency of occurrence in the predated samples are omitted for clarity.

Journal of Cave and Karst Studies, December 2012•273 


\section{Results}

No newt mortality was observed during or after stomach flushing. The sex ratio of Triturus carnifex was $0.5(n=22)$ and the stomach vacuity was $9 \%$. Thus, we obtained data on the diet of ten male and ten female Italian crested newts. Sexes did not differ significantly in body size and weight $(n=20$; snout-vent length $=6.37 \pm$ $0.44 \mathrm{~cm}$ and $6.20 \pm 0.25 \mathrm{~cm}$ for females and males, respectively; weight $=8.26 \pm 1.80 \mathrm{~g}$ and $8.33 \pm 1.20 \mathrm{~g}$ for females and males, respectively; $p>0.1$ for all comparisons).

The results of sampling available prey are presented in Table 1. Based on their taxonomy and ecology, terrestrial or aquatic, the prey detected in stomach contents were divided into nine groups plus undetermined insects (Table 2). Overall, lepidopterans (Cataclysta lemnata) and dipterans were preyed upon by newts most frequently $(95 \%$ and 55\% respectively; Table 2). Invertebrates that would appear on the horizontal axis in Figure 2 are those that are available in the environment but were not eaten by the newts.

The average number of prey per stomach was $7.55 \pm$ 11.66 and $5.22 \pm 8.52$ for males and females, respectively, and did not differ significantly (Mann-Whitney, $\mathrm{U}=38, p$ $=0.82$ ). There was no overall difference in the diet composition between the sexes (ANOSIM, $n=20$; global $R=-0.06, p=0.92$ ). Table 2 shows the numbers in each prey group found in the stomachs of males and females. Table 3 shows the diversity indexes for stomach and feces separately, with the sexes pooled, and for stomach contents for the sexes separately. The correlation between STO and FEC was not significant (flying diptera was pooled with the diptera that were not Tipulidae, giving $n=9 ; r=0.34, p=$ 0.37 ), suggesting that some prey groups were degradated during digestion.

The overall richness of the types of invertebrates listed in Table 1 in the diet of Triturus carnifex, pooling the stomach and fecal contents, was less than trophic availability $(n=15 ; r=-0.17, p=0.95)$. The numbers of groups preyed upon was eight and five, respectively, for females and males (Table 2). In the modified Costello's graphic representation (Fig. 2), almost all prey items are in the lower left corner, while Cataclysta lemnata is in the upper right quadrant.

\section{DisCUSSION}

The occurrence in the sinkhole Pozzo del Merro of the endemic amphipod Niphargus cornicolanus and the newt Triturus carnifex was the main motivation to study the trophic niche of the Italian crested newt. If a preypredator relationship was demonstrated, conservation implications concerning these species, the former strictly endemic and the latter protected by the European Directive 92/43/EEC, would have to be considered.
Niphargus specimens are often preyed upon by newts, and in general, by aquatic salamanders, in cases where they share the same microhabitat (Racca et al., 2002; Schabetsberger and Jersabek, 1995). However, in the Pozzo del Merro, N. cornicolanus is found mainly between 10 and $20 \mathrm{~m}$ of depth, and occasionally up to $74 \mathrm{~m}$ (Palozzi et al., 2010; R. Palozzi, unpublished data). In the study site, T. carnifex has been found (by RP) only up to 7 or $8 \mathrm{~m}$ deep, but definite data on this issue are lacking. Since many newts feed at more than $8 \mathrm{~m}$ of depth (Schabetsberger and Jersabek, 1995), and at least up to $12 \mathrm{~m}$ (George et al., 1977), a small overlap in the depth distributions of $T$. carnifex and $N$. cornicolanus seems possible. However, Niphargus cornicolanus was not found in the newt diet. The presence of Niphargus in the newt diet cannot be completely rejected, due to our limited sample size. However, even if it is preyed upon, the amphipod appears to be a relatively rare prey item, and its conservation, in relation to the potential predation of this large Italian newt, should not require specific measures or management plans.

Triturus carnifex feeds primarily on aquatic animals and on terrestrial arthropods falling on the water surface, showing a generalist dietary habit (Fasola and Canova, 1992; Ancona and Bolzern, 1993; Vignoli et al., 2009). However, the feeding strategy of the Italian crested newt in the Pozzo del Merro revealed that there is a dominant food item, the larvae of the lepidopteran Cataclysta lemnata, the point for which is in the upper right corner of Figure 2 and which has high specific abundance in the water and high occurrence in samples of prey remains. The population of $T$. carnifex inhabiting the sinkhole Pozzo del Merro is specializing in this one prey type. Almost all individuals had been feeding on the dominant prey, but a significant proportion of other available prey was included occasionally in the diet of some individuals (Table 1; Fig. 2). Since prey types range from the upper right to the lower left in Figure 2, the newt population possesses a relatively broad trophic niche. The diet of males and females was similar, but the number of taxa in the female stomachs was twice that of the males, and the confidence limit of the number of taxa diversity index (Table $3 \mathrm{~b}$ ) are just slightly overlapping, suggesting that analysis of a larger sample could allow a difference to be statistically confirmed. The comparison of the data obtained from fecal and stomach analyses is also interesting. Indeed, the study of fecal samples in salamanders may lead to a drastic underestimate in the number and diversity of prey taxa (Table 3a), because small and delicate prey tend to be completely digested by salamanders (Corvetto et al., 2012). This selective digestion may be a problem when searching for specific prey-predator relationships in a given context. Therefore, the use of stomach flushing should be preferred to fecal sampling, which does not assure a complete evaluation of a salamander's diet. 
A. Romano, S. Salvidio, R. Palozzi, and V. Sbordoni

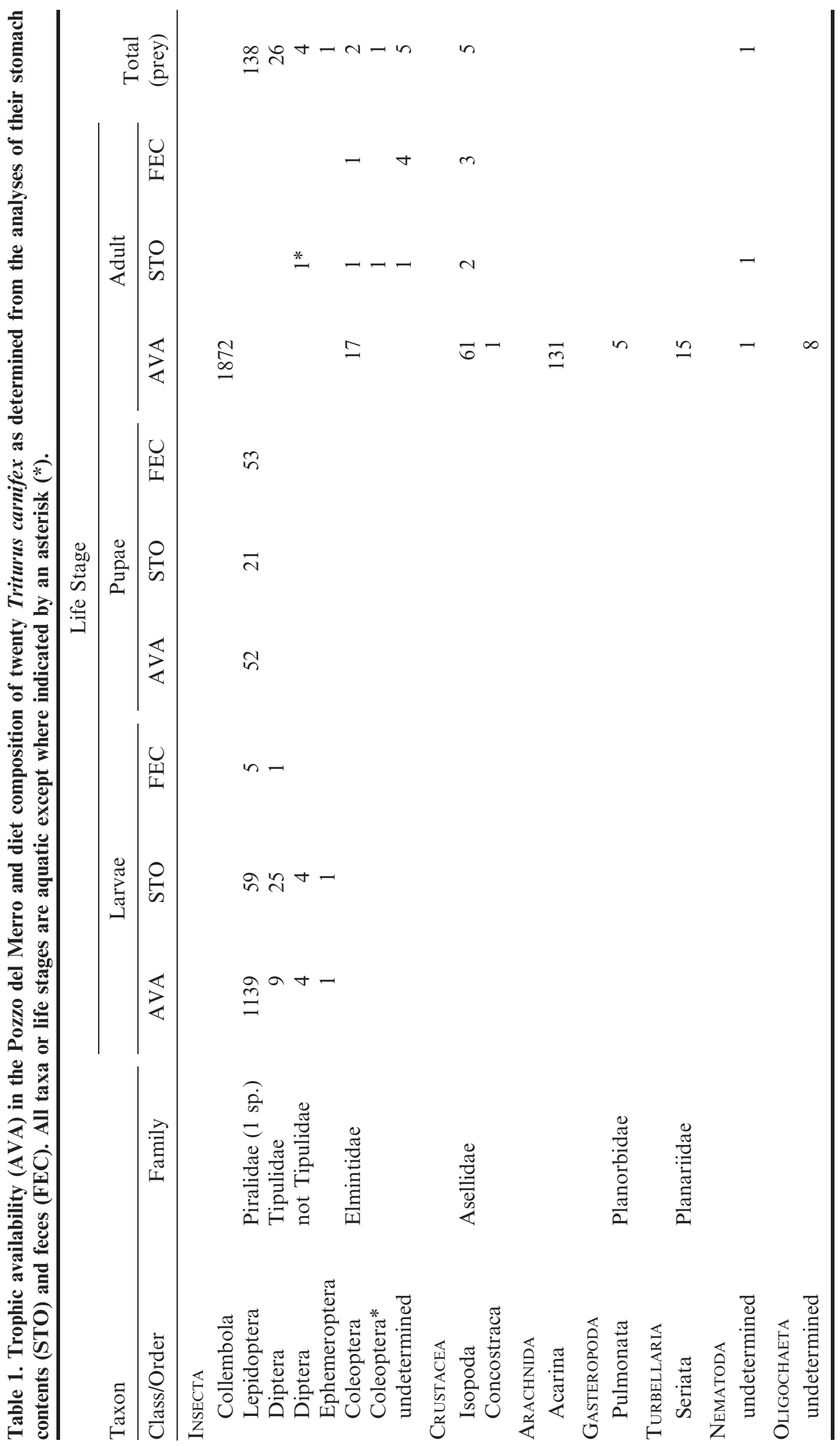

Journal of Cave and Karst Studies, December 2012•275 
Diet of the newt, Triturus Carnifex (Laurenti, 1768), in the flooded Karst sinkhole Pozzo del Merro, Central Italy

Table 2. Summary of the number of specimens of prey found in stomachs only for groups of the taxa in Table 1, sorted by female (FF) and male (MM). The percentage of the ten newts of each species that had eaten each group is also given.

\begin{tabular}{|c|c|c|c|c|c|c|}
\hline \multirow[b]{2}{*}{ Organism } & \multicolumn{2}{|r|}{ FF } & \multicolumn{2}{|c|}{ MM } & \multicolumn{2}{|c|}{ Total } \\
\hline & $\mathrm{N}$, prey & $\%$ of newt & $\mathrm{N}$, prey & $\%$ of newt & $\mathrm{N}$, prey & $\%$ of newt \\
\hline Lepidoptera (Cataclysta lemnata) & 37 & 90 & 43 & 100 & 80 & 95 \\
\hline Diptera Tipulidae (larvae) & 11 & 30 & 20 & 50 & 21 & 40 \\
\hline Diptera non Tipulidae (larvae) & 5 & 10 & 3 & 20 & 8 & 15 \\
\hline Flying Diptera (terrestrial and not Tipulidae) & 1 & 10 & 0 & 0 & 1 & 5 \\
\hline Ephemeroptera (larvae) & 1 & 10 & 0 & 0 & 1 & 5 \\
\hline Coleoptera (aquatic); & 1 & 10 & 0 & 0 & 1 & 5 \\
\hline Coleoptera (terrestrial) & 1 & 10 & 0 & 0 & 1 & 5 \\
\hline Insecta undetermined & 1 & 10 & 0 & 0 & 1 & 5 \\
\hline Crustacea, Asellidae & 0 & 0 & 2 & 10 & 2 & 5 \\
\hline Nematoda & 0 & 0 & 1 & 10 & 1 & 5 \\
\hline Total & 58 & & 69 & & 117 & \\
\hline
\end{tabular}

\section{CONCLUSIONS}

This paper is the first study on the feeding behavior of a newt in a deep, flooded karst sinkhole. A previous study on the diet of newts during the 2003-2009 invasion of Salvinia molesta would have been useful to determine the effect of this invasive plant on the newt population. The importance of the native aquatic plant Lemna minor in sustaining the population of Triturus carnifex was strongly suggested by the present study. Alterations to the natural status of this karst ecosystem, such as the permanent replacement of autochthonous Lemna with Salvinia, could likely lead to ecological consequences, because the most importance food resource used by newts in the summer would be unavailable.

Other Italian crested newt populations living in different ecosystems such as shallow karst ponds and other lakes seem to be characterized by an opportunistic feeding behavior (Vanni et al., 2007). A study of a population from a flooded tuff quarry abandoned in central Italy suggested the Triturus carnifex may have a mixed feeding strategy (dominant-generalized) and some individuals may feed on prey with a relatively high frequency of occurrence (Vignoli et al., 2009). The population living in the Pozzo del Merro exhibited, at least in the summer, a different feeding behavior, because all newts were specialized predators of an invertebrate with high frequency of occurrence. Generalist feeding behavior of $T$. carnifex in habitats with variable environmental parameters may vary slightly over seasons and years, depending on resources (Ancona and Bolzern, 1993). Although in the sinkhole physical and chemical parameters are relatively stable (Palozzi et al., 2010), further research should aim at establishing the feeding strategy adopted by the Italian crested newts during the fall and winter, when the plant Lemna minor and the associated small China-mark Cataclysta lemnata are absent. Furthermore, in winter time, pleustonic prey would become less available, and the newts might move deeper in the water to forage on Niphargus.

Finally, the analysis of the diet of the smaller smooth newt Lissotriton vulgaris and of Triturus carnifex larvae, which may show a specialization towards aquatic crustaceans (Vignoli et al., 2009; Stoch and Dolce, 1984), should also be undertaken to completely reveal the trophic relationships between the endemic Niphargus cornicolanus and the sympatric amphibians which live in the Pozzo del Merro.

Table 3. Indexes of prey taxa diversity, with 95\% confidence limits, of Triturus carnifex in the Pozzo del Merro (Central Italy).

\begin{tabular}{|c|c|c|c|c|c|c|c|c|c|c|c|c|}
\hline \multirow[b]{4}{*}{ Index Type } & \multicolumn{6}{|c|}{$\begin{array}{l}\text { Stomach and Fecal Contents Compared for } \\
\text { Pooled Male and Female Specimens }\end{array}$} & \multicolumn{6}{|c|}{$\begin{array}{c}\text { Stomach and Fecal Contents Compared for } \\
\text { Females and Males }\end{array}$} \\
\hline & \multicolumn{3}{|c|}{ STO (sexes pooled) } & \multicolumn{3}{|c|}{ FEC (sexes pooled) } & \multicolumn{3}{|c|}{$\begin{array}{l}\text { Diversity STO } \\
\text { Females }\end{array}$} & \multicolumn{3}{|c|}{ Diversity STO Males } \\
\hline & & \multicolumn{2}{|c|}{$\begin{array}{l}\text { Boostrap } \\
(95 \%)\end{array}$} & & \multicolumn{2}{|c|}{$\begin{array}{l}\text { Boostrap } \\
(95 \%)\end{array}$} & \multicolumn{3}{|c|}{$\begin{array}{l}\text { Boostrap } \\
(95 \%)\end{array}$} & & \multicolumn{2}{|c|}{$\begin{array}{l}\text { Boostrap } \\
(95 \%)\end{array}$} \\
\hline & & Min. & Max. & & Min. & Max. & & Min. & Max. & & Min. & Max. \\
\hline Index of Taxa Diversity & 9 & 5 & 9 & 5 & 3 & 5 & 8 & 3 & 8 & 4 & & 4 \\
\hline Simpson Index & 0.476 & 0.371 & 0.552 & 0.245 & 0.114 & 0.38 & 0.392 & 0.226 & 0.539 & 0.511 & 0.394 & 0.590 \\
\hline
\end{tabular}




\section{ACKNOWLEDGEMENTS}

Capture and stomach flushing were performed with the permit from the Ministero dell'Ambiente e della Tutela del Territorio e del Mare (permit reference: DPN/2010/ 0002708). The Province of Rome provided the research grant for this study. We are indebted to Giovanni Forcina for help in field sampling. We thank two anonymous referees for many useful suggestions that surely improved our manuscript.

\section{REFERENCES}

Amundsen, P.-A., Gabler, H.-M., and Staldvik, F.J., 1996, A new approach to graphical analysis of feeding strategy from stomach contents data-modification of the Costello (1990) method: Journal of Fish Biology, v. 48, no. 4, p. 607-614. doi:10.1111/j.10958649.1996.tb01455.x.

Ancona, N., and Bolzern, A.M., 1993, Alimentazione di Triturus carnifex e T. vulgaris meridionalis (Amphibia Caudata) in due stagni dell'Appenino Ligure: Rendiconti Scienze Chimiche e Fisiche, Geologiche, Biologiche e Mediche, Istituto Lombardo, v. B126, p. $123-137$.

Andreone, F., and Marconi, M., 2006, Triturus carnifex (Laurenti, 1768), in Sindaco, R., Doria, G., Razzetti, E., and Bernini, F., eds., Atlante degli Anfibi e dei Rettili d'Italia / Atlas of Italian Amphibians and Reptiles: Firenze, Societas Herpetologica Italica, Edizioni Polistampa, p. $220-225$.

Caramanna, G., 2002, Exploring one of the world's deepest sinkholes: the Pozzo del Merro (Italy), Underwater Speleology, February, p. 4-8.

Clarke, K.R., 1993, Non-parametric multivariate analysis of changes in community structure: Australian Journal of Ecology, v. 18, p. 117-143. doi:10.1111/j.1442-9993.1993.tb00438.x.

Costello, M.J., 1990, Predator feeding strategy and prey importance: a new graphical analysis. Journal of Fish Biology, v. 36, no. 2, p. 261-263. doi:10.1111/j.1095-8649.1990.tb05601.x.

Crovetto, F., Romano, A., and Salvidio, S., 2012, A comparison of two non-lethal methods for dictary studies in terrestrial salamanders. Wildlife Research, v. 39, p. 266-270.

Fasola, M., and Canova, L., 1992, Residence in water by the newts Triturus vulgaris, $T$. cristatus and T. alpestris in a pond in northern Italy: Amphibia-Reptilia, v. 13, no. 3, p. 227-233. doi:10.1163/ 156853892 X00436.

Gary, M.O., Sharp, J.M. Jr., Caramanna, G., and Havens, R.H., 2003, Volcanically influenced speleogenesis: forming El Sistema Zacatón, Mexico, and Pozzo del Merro, Italy, the deepest phreatic sinkholes in the world: Geological Society of America Abstracts with Programs, vol. 34, no. 7, session 19-4, 52 p.

George, C.J., Boylen, C.W., and Sheldon, R.B., 1977, The presence of the red-spotted newt, Notophthalmus viridescens rafinesque (Amphibia, Urodela, Salamandridae) in waters exceeding 12 meters in Lake George, New York: Journal of Herpetology, v. 11, no. 1, p. 87-90.

Giardini, M., 2003, Note sulla biologia, l'ecologia e le modalità di controllo di Salvinia molesta D.S. Mitchell (Salviniaceae), specie infestante nuova per il Lazio: Rivista di Idrobiologia, v. 42, no. 1-3, p. $263-282$.

Giardini, M., 2004, Salvinia molesta D.S. Mitchell (Salviniaceae): seconda segnalazione per l'Italia (Lazio) e considerazioni sul controllo di questa specie infestante: Webbia, v. 59, no. 2, p. 457-467.

Weber, A., Amphibia, in Gunn, J., ed., Encyclopedia of Caves and Karst Science: New York, Fitzroy Dearborn, p. 61-62

Iannilli, V., and Vigna Taglianti, A., 2005, New data on genus Niphargus (Amphipoda, Niphargidae) in Italy, with the description of a new species of the Orcinus group: Crustaceana, v. 77, no. 10 (2004), p. 1253-1261. doi:10.1163/1568540043166029.
Joly, P., 1987, Le régime alimentaire des amphibians: méthodes d'étude: Alytes, v. 6, no. 1-2, p. 11-17.

Köhler, J., Vences, M., D'Cruze, N., and Glaw, F., 2010, Giant dwarfs: discovery of a radiation of large-bodied 'stump-toed frogs' from karstic cave environments of northern Madagascar: Journal of Zoology, v. 282, no. 1, p. 21-38. doi:10.1111/j.1469-7998.2010.00708.x.

Lewin, J., and Woodward, J.C., 2007, Karst geomorphology and environmental change, in Woodward, J., ed., The Physical Geography of the Mediterranean: Oxford, Oxford University Press, p. 287-317.

Magurran, A.E., 2004, Measuring Biological Diversity: Malden, Massachusetts, Blackwell Publishing, 256 p.

Palozzi, R., Caramanna, G., Albertano, P., Congestri, R., Bruno, L., Romano, A., Giganti, M.G., Zenobi, R., Costanzo, C., Valente, G., Polani, D., Vecchio, M., Vinci, M., and Sbordoni, V., 2010, The underwater exploration of the Merro sinkhole and the associated diving physiological and psychological effects: Underwater Technology, v. 29 , no. 3 , p. $125-134$. doi:10.3723/ut.29.125.

Racca, L., Bressi, N., Dolce, S., and Giacoma, C., 2002, Studio etologico del comportamento alimentare di Proteus anguinus anguinus (Amphibia, Urodela) in cattività: Atti Museo Civico di Storia Naturale di Trieste, v. 49 , p. $157-167$

Romanazzi, E., and Bonato, L., 2011, Anfibi sul Montello: Distribuzione dei siti riproduttivi in un territorio carsico prealpino, in Bon, M., Mezzavilla, F., and Scarton, F., eds., Atti del $6^{\circ}$ Convegno dei Faunisti Veneti: Bollettino del Museo civico di Storia Naturale, Venezia, suppl. to, v. 61, p. 88-95.

Romano, A., Ventre, N., De Riso, L., Pignataro, C., and Spilinga, C., 2010, Amphibians of the "Cilento e Vallo di Diano" National Park (Campania, Southern Italy): updated check list, distribution and conservation notes. Acta Herpetologica, v. 5, no. 2, p. 233-244.

Salvidio, S., 1992, Diet and food utilization in a rockface population of Speleomantes ambrosii (Amphibia, Caudata, Plethodontidae): Vie et Milieu, v. 42, no. 1, p. 35-39.

Schabetsberger, R., and Jersabek, C.D., 1995, Alpine newts (Triturus alpestris) as top predators in a high-altitude karst lake: daily food consumption and impact on the copepod Arctodiaptomus alpinus: Freshwater Biology, v. 33, p. 47-61. doi:10.1111/j.1365-2427.1995.tb00385.x.

Schabetsberger, R., Jersabek, C.D., and Brozek, S., 1995, The impact of Alpine newts (Triturus alpestris) and minnows (Phoxinus phoxinus) on the microcrustacean communities of two high altitude karst lakes: Alytes, v. 12, no. 4, p. 183-189.

Schmitter-Soto, J.J., Comin, F.A., Escobar-Briones, E., Herrera-Silveira, J., Alcocer, J., Suárez-Morales, E., Elias-Gutiérrez, M., Díaz-Arce, V., Marín, L.E., and Steinich, B., 2002, Hydrogeochemical and biological characteristics of cenotes in the Yucatan Peninsula (SE Mexico): Hydrobiologia, v. 467, no. 1-3, p. 215-228. doi:10.1023/A:1014923217206.

Sket, B., 1997, Distribution of Proteus (Amphibia: Urodela: Proteidae) and its possible explanation: Journal of Biogeography, v. 24, no. 3, p. 263-280. doi:10.1046/j.1365-2699.1997.00103.x.

Stoch, F., and Dolce, S., 1984, Alimentazione e rapporti alimentari di Triturus alpestris alpestris (Laur.), Triturus cristatus carnifex (Laur.) e Triturus vulgaris meridionalis (Boul.). (Osservazioni sull'alimentazione degli Anfibi: III): Quaderni ETP, Rivista di Limnologia, Udine, v. 9, p. $17-28$.

Vanni, S., Andreone, F., and Tripepi, S., 2007, Triturus carnifex (Laurenti, 1768), in Lanza, B., Andreone, F., Bologna, M., Corti, C., and Razzetti, E., eds., Fauna d'Italia XLII: Amphibia, Bologna, Edizioni Calderini, p. 265-272.

Vignoli, L., Bombi, P., D’Amen, M., and Bologna, M.A., 2007, Seasonal variation in the trophic niche in a heterochronic population of Mesotriton alpestris apuanus (Amphibia, Salamandridae) from the south-western Alps: Herpetological Journal, v. 17, p. 183-191.

Vignoli, L., Luiselli, L., and Bologna, M.A., 2009, Dietary patterns and overlap in an amphibian assemblage at a pond in Mediterranean central Italy: Vie et Milieu / Life and Environment, v. 59, no. 1, p. 47-57.

Wilson, K., and Hardy, I.C.W., 2002, Statistical analysis of sex ratios: an introduction, in Hardy, I.C.W., ed., Sex Ratios - Concepts and Research Methods: Cambridge, Cambridge University Press, p. $48-92$. 